DOI: $10.15503 /$ jecs20162.398.407

\title{
TEACHING LANGUAGE AND SPEECH TO STUDENTS OF STAGE ACTING (ADU IN ZAGREB AND AGRFT IN LJUBLJANA)
}

KAROLINA VRBAN ZRINSKI

Academy of Dramatic Art, University of Zagreb

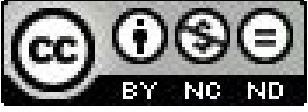

Trg maršala Tita 5, Zagreb, Croatia

E-mail address: kzrinski@ffzg.hr

NINA ŽAVBI MILOJEVIĆ

University of Ljubljana, Academy of Theatre, Radio, Film and Television

Nazorjeva ulica 3, Slovenia

E-mail address: nina.zavbi.milojevic@gmail.com

\begin{abstract}
In the article we describe the methods of teaching language and speech at the Academy of Dramatic Art in Zagreb (Croatia) and at the Academy of Theatre, Radio, Film and Television in Ljubljana (Slovenia). We start by describing how language and speech are taught as individual subjects, we present the trends in teaching language and speech and compare the teaching practices at both academies. The main part of the article intends to show the connection between theory and practice in teaching, which should result in a stronger connection between the scientific and artistic approach in teaching. The goal of comparing the teaching practices at both academies is to show the similarities and differences in teaching and to explicitly present models of teaching and models of assessing the speech of actors, which have proved to be indisputable according to the comparison.
\end{abstract}

Key words: teaching actors, language and speech, stage speech, orthoepy, speech stylistics

\section{INTRODUCTION}

In this paper we describe the particularities of language and speech learning at two academies: the Academy of Dramatic Art (ADU) in Zagreb, University of Zagreb, Croatia and the Academy of Theatre, Radio, Film and Television (AGRFT) in Ljubljana, University of Ljubljana, Slovenia. These are two similar academies, not only in terms of physical distance, but also in terms of linguistic features (the Slavic languages). However, this close connection between the two academies dates back to the first half of the $20^{\text {th }}$ century when Croatian and Slovenian playwrights were cooperating intensely. 
Slovenian actors and directors (such as Vika Podgorska, Marija Vera, Hinko Nučić) performed and worked in Croatian theatres, while Croatian actors and directors performed and worked in Slovenian theatres (for example, Zvonimir Rogoz, Branko Gavella), which significantly influenced the shaping of similar aesthetic criteria regardless of language differences (Podbevšek \& Vrban Zrinski, 2013, p. 92). Those aesthetic criteria could be identified in the pedagogical work with future actors (i.e. Branko Gavella). The starting point for our comparison of the contemporary language and speech teaching to acting students are the descriptions of instruction in some courses of language and speech. That is, we are presenting the guidelines for language and speech teaching and the comparison of teaching methods used with students at the two academies.

At first, AGRFT in Ljubljana was focused primarily on the theatre. Then the Academy "expanded to include other profiles conditioned by the development of other types of audio-visual media (the radio, film, television). The authors of the first study programmes knew well that practical education itself was not sufficient and that the Academy had to become the centre of the theoretical thinking regarding the theatre [...]. The duality of theory and practice has been maintained to the present"1 (Podbevšek, 2006, p. 7).

A director and a teacher at the Academy of Dramatic Art in Zagreb, Branko Gavella (1967), wrote about phonetics and its significance as a new science and claimed that phonetics has to nurture stage speech both from the scientific and practical aspect. However, up to the present day Croatian theatres have based their evaluation of actors' speech on their talent and accurate accent. In scientific and theoretical thinking it is evident that the same level of importance has to be attached to other prosodic factors as well (Varošanec-Škarić, 2010). Following that train of thought, it is important to emphasize that recent research on the contemporary Croatian stage speech has shown that the most reliable indicator of the final grade of an actor or an actor's success in the stage speech domain is speech smoothness, followed by logical emphasizing and intonation, pleasant tone of voice and expressiveness, while the accent was not found to be a discriminant variable (Vrban Zrinski, 2013c).

\section{LANGUAGE AND SPEECH INSTRUCTION}

Taking into consideration research results, the actual needs of the profession and research approach, at the ADU in Zagreb the following courses in phonetics and the Croatian language are taught: Croatian Stress Patterns, Orthoepy of the Croatian Language, Linguistic Purism and Speech Elegance, and Styles of the Croatian Language and Speech. All four courses in the Croatian language are taught by Karolina Vrban Zrinski. The courses are designed for first- and second-year undergraduate students of Acting and of

1 All quotes that are originally in the Slovene and Croatian language were translated into English by Mirta Kos Kolobarić. 
Theatre Directing and Radiophony (Broadcasting). The course Stage Speech, which is taught at the ADU in Zagreb throughout all three years in undergraduate study programme and two years in graduate study programme in acting, is run by teachers who hold artistic-teaching positions, actors such as Tomislav Rališ, Suzana Nikolić, Ivana Legati, Marina Petković Liker and external associates. Stage Speech from the first to the fifth year of study falls within the scope of the Chair of Stage Speech.

According to recent research in stage speech in theatres it is evident that the disciplines such as orthophony, orthoepy and dialects play a key part in future actors' education (Vrban Zrinski, 2013a; Vrban Zrinski 2013c). It can be said that the absence of courses in linguistics is felt in other departments of the Academy of Dramatic Art in Zagreb, which has eight departments: Acting, Theatre Directing and Radiophony, Film and TV Directing, Cinematography, Editing, Dramaturgy, Production and Contemporary Dance and Ballet Pedagogy.

Nowadays at the Academy of Theatre, Radio, Film and Television in Ljubljana Stage Speech is taught very systematically at the Chair of Speech, which is composed of pedagogues, artists - actors and scientists - Slovenists. In the undergraduate study programme first of all actors and theatre directors are educated and in the teaching process teachers constantly intertwine theoretical knowledge with practice, which is evident in all other courses that are taught, as well as in the Stage Acting study programme. "At the Chair of Speech we are making an effort to symbiotically intertwine practice with theory and at the same time to conduct systematic interdisciplinary research on processes which take place during the shaping of (artistic) speech and to keep up to date with the latest achievements in various scientific fields which can be useful to us" (Podbevšek, 2006, p. 7).

Speech is taught throughout all four years of undergraduate study programme Stage Acting. It is continuously taught within three courses: Language and Speech I, II and III. Katarina Podbevšek and Nina Žavbi Milojević constantly try to combine lectures on certain topics and practice which places the theory in the field of an actor's interest. It has been proved in the long-standing teaching practice that it is vital for students of Stage Acting to understand that theoretical knowledge gained in lectures is connected to the actual practice. If that connection is clear, students' interest is great, they acquire more knowledge, ask critical questions, counter the teacher's arguments, try to apply that knowledge to the plays they have seen, the production they are preparing in the course Stage Acting, etc. However, if they believe that the theory taught by teachers is not applicable to the practice, they lose interest and desire to participate. Theory itself is not a favourite among Stage Acting students, so it should constantly be made interesting. The cooperation between teachers who teach courses in skills (speech, movement, etc.) and teachers who teach Stage Acting and Directing is of vital importance. It presents a direct link between the theory and practice on the one hand, and science and art on the other, showing the students the importance of cooperation and (theoretical) knowledge acquisition. 


\section{CROATIAN STRESS PATTERNS (ADU)}

Croatian Stress Patterns as a course is taken during the winter semester in the first year of undergraduate study programme in Acting. Stress in Croatian words is learned on the level of distribution of stress (stress rules), listening recognition and pronunciation. Topics covered in lectures encompass the opposing rules and exceptions to the stress norms, due to the specific nature of stage speech which depicts various sociological, psychological, stylistic and other features of dramatic personae. Practice involves listening to the carefully chosen stress paradigms and recognizing and marking stress and stress length, as well as marking stress in texts.

The results of the listening test in stress recognition taken at the end of the semester show a high level of recognition of stress placement and quality, which is a very important ability for future actors, since it is a precondition for accurate pronunciation of stress pattern, as well as an indicator of speech elasticity which is important for presentation of various spoken images of dramatic personae. Stress placement is recognized with $90 \%$ accuracy. Croatian has 4 stress patterns. According to the test, the best recognized stress is long falling stress, followed by long rising and short rising stress, while students mostly struggled with recognizing the short falling stress. These results can be compared with the results achieved by other students, for example, in phonetics (Vrban Zrinski \& Varošanec-Škarić, 2004). It should be noted that students had learned about the Croatian stress patterns only 3 months before they took a listening test, with regular, everyday practice in listening and pronunciation of word stress in Stage Speech lessons.

\section{LANGUAGE AND SPEECH 1 (AGRFT)}

Language and Speech 1, as a course, covers topics in the field of phonetics, with special attention being paid to orthoepy. Students deepen their knowledge of language and speech phenomena in general, recognize the particularities of artistic language and speech, analyse their own speech and function on stage, are introduced to the Slovene sound system and orthoepy (Prospectus: First cycle degree study programme: Stage acting, 2015, p. 17). Language and Speech 1 is composed of three courses: Introduction to Stage Speech, Sociolinguistics and Phonetics. All three courses combine lectures (theory) and practice. Introduction to Stage Speech comprises practice in the so-called speech imagination and practice in orthoepy, in which special attention is paid to vowels, i.e. to strong stress in the standard Slovene language, as well as to sound changes which present a difference between the written and pronounced consonants. Throughout practical lessons in the so-called speech imagination Katarina Podbevšek encourages students to observe their own and speech of others, to become aware of the specificity of their own speech and to try to assume different sound and speech roles. Students attempt to imitate various sounds (other people's voices, animals, a squeaky door, the 
squeaking of snow under our feet, a howling wind), to describe their voices using metaphoric expressions (colour, what my voice would be if it were an instrument, etc.), to change their voices. In Phonetics course they are introduced to the vowel and consonant system in the standard Slovene language, they learn about human speech organs, about human speech as a thinking process (brain and its role in speech), as well as about practical phonetics, forensic phonetics, etc. They also learn about technologies which phoneticians use in speech analysis and about the usefulness of such technology in stage speech analysis. In this way they are shown that the knowledge of phonetics can be very important and useful for actors. All of these things are taught during practical lessons which are an integral component of all courses in language and speech.

\section{ORTHOEPY OF THE CROATIAN LANGUAGE (ADU)}

Speech symptoms and images are related to what is being conveyed by voice in a broad sense, while the text implies everything that is conveyed through language. Speech image consists of a textual component and speech performance (Škarić \& Varošanec-Škarić, 1994), while speech performance is broken down into voice analysis, vowel pronunciation, consonant pronunciation, stress, speech faults and errors, logical emphasis and logical pauses, rhythm and pace of speech and smoothness analysis (Varošanec-Škarić, 2010). Bearing that in mind, the aim of this course is to make students aware of their own speech patterns in order to improve them and in order to avoid potential discomfort and fear of public performance due to certain faults that can be corrected, such as syncopation, diphthongization, mispronunciation of vowels, inability to pronounce four-stress pattern in the Croatian language, etc. Orthoepy is taught to first-year students of acting in the summer semester.

This course includes teaching students the basic rules of pronunciation, the most frequent speech errors and faults, vocalism, dialectalism, assimilation, spoken language values (Vuletić, 2007), word and sentence stress, i.e. intonation unit and utterance nucleus (Ivas, 1993), oxytonic rhythm (stress falls on the final word) and baritone rhythm (stress falls on the non-final words in intonation units). Practical work in orthoepy is done on a chosen text, with special attention being paid to logical stress or logical emphasis of a word as a vital prosodic factor in the stage speech of an actor, since it is the logical emphasis that conveys a range of information and directs the further flow of dramatic events. It is also a warning that logical emphasis should not be heard from the stage (Vrban Zrinski, 2013b). Assessment protocols and speech learning can be divided into five categories: voice, pronunciation, expressiveness, fluency and overall grade (Vrban Zrinski, 2013c). The methods and content of this course are similar to the syllabus for courses Language and Speech 1 and 2 at AGRFT. 


\section{LANGUAGE AND SPEECH 2 (AGRFT)}

The course Language and Speech 2 includes textual phonetics, where again theory and practice is brought together. Students are introduced to theoretical basis of speech along with the analysis of prosodic elements and to non-verbal language with emphasis placed on the semantic value of audio-visual signs in artistic speech (Prospectus: First cycle degree study programme: Stage acting, 2015, p. 17). Special attention is payed to prosodic devices (strength, i.e. loudness, pauses, register, intonation, voice quality, voice modulation, pace of speech) and non-verbal communication elements (gestures, mimics, body posture, proxemics), taking into consideration stage performance and stage speech. All prosodic features are applied to various spoken texts. Students analyse them and observe their function in a text.

\section{LINGUISTIC PURISM AND SPEECH ELEGANCE (ADU)}

The title of this course refers to linguistic purism which exhibits the linguistic standard, eloquence, the manner of speech (from pseudolalia to archetypal speech), while speech elegance is manifested in cultivated speech, refinement, aesthetic qualities of speech, appropriate proxemic relationships and good speaking manners (Škarić, 1995). This course is designed for second-year students in the winter semester. The study of language and speech is primarily focused on the standard language, not stylistic variations in dramatic texts or peculiarities of artistic and literary styles which mostly encompass dramatic texts. The course can be viewed as a certain bridge between the dialects spoken by students and artistic speech. Students have written assignments (2-3 pages long) and can write about topics of their choice. After that their papers are presented according to the rhetorical rules, from complying with the requested presentation duration (3 minutes), speech composition, speaking (instead of reading), proxemic relationships to good speaking manners.

After each presentation we analyse the language and speech of each respective student. The analysis shows that speech images of students are actually the symptoms of their private images of speech, while non-verbal signs are mostly unrelated to the verbal content. We have recorded a great number of linguistic errors and linguistic variations, as well as faults in speech, which should not be detected in actors' profession. Speech elegance lacks modal expressions, figurative expressions and humour. A too frequent choice of baritone rhythm, quick pace of speech, unprepared intonation units, inappropriate pauses in speech, infantile intonation patterns of rising and flat tone and nasal voice are prosodic devices which point to our students' manners, that is, they show that speech images are actually the symptoms of private images of speech, not the appropriate speech image for that particular presentation. The results actually predict potential difficulties which will emerge in learning stage speech, and also point to the type of phonetic exercise which should be done with students individually. 


\section{LANGUAGE AND SPEECH 3 (AGRFT)}

Language and Speech 3 covers the topics in stylistics and versology, with primary focus on those chapters that are necessary for actors in the actual practice - for example, the style of a dramatic text and performance, the verse system with emphasis on the dramatic verse, etc. In this course students study the verse system, while in practical lessons students are mainly focused on verse pronunciation (enjambment, rhyme, verse, metric features, etc.). The theme overlaps with the main study course Stage Acting, in which third-year students work on dramatic texts in the verse form.

\section{THE STYLES OF THE CROATIAN LANGUAGE AND SPEECH (ADU)}

The fourth course at the ADU in Zagreb is The Styles of the Croatian Language and Speech, which is taken in the summer semester in the second year of undergraduate acting study programme. The course aim is to adopt the basic stylistic terminology, stylistic values of the Croatian language and its features regarding the style, medium and various functional linguistic styles (Silić, 2006) and various speech styles (Varošanec-Škarić, 1995). Throughout the course students study stylistic terminology, such as semantostylemes, verbless sentences, poetic and rhetorical devices as a preparation for independent linguistic and stylistic text analysis. A significant feature of this course is to learn how to differentiate between the standard feature of expression and its variation, i.e. free choice of words and phrases in literary and artistic texts. We can conclude that the subject content of this course, The Styles of the Croatian Language and Speech at the ADU in Zagreb is similar to, and in some cases the same, as the content taught in Language and Speech 3 course at the AGRFT in Ljubljana.

Apart from the analysis of students' papers in lessons, we also carry out phonetic listening assessment of the actors' speech in various styles and time frames. Listening to the speech performance students have a task to recognize when a dramatic text is spoken in prose, and when in verse. Then, according to the prosodic features or the manner of speech, students are expected to determine when the main character is speaking and when other characters are speaking. They are also supposed to assess the level of their persuasiveness. It is interesting to note that the phonetic listening assessment of the actors' speech shows that students, bearing in mind the particularities of the actors' speech or prosodic features find it easy to recognize sadness, while other emotions, such as fear, love, happiness or anger are more difficult to recognize (Podbevšek \& Vrban Zrinski, 2013). 


\section{CHAIR OF SPEECH (AGRFT)}

Apart from Katarina Podbevšek and Nina Žavbi Milojević, three more lecturers work at the Chair of Speech, all three of them being actors. In the first three years of study students of acting and directing take a course Speech Technique, taught by Tomaž Gubenšek and Alida Bevk. The course content is an introduction to and awareness of various breathing techniques, breathing and phonation, and the Slovene vowel and consonant system. In fact, it is a theoretical and practical introduction, considering the dialects used by students, as well as articulatory preparation for speaking and analysis of sentence and phonetic rules in the analysis of a classical text in Slovene. Students correct their vowels and gain practical knowledge in phonetics (Prospectus: First cycle degree study programme: Stage acting, 2015, pp. 20-21).

Speech Technique as a course is related to another course, Stage Speech 1 and 2, which is taught by Vladimir Jurc to third- and fourth-year students of Stage Acting. Within this course students practice various speech techniques working on different literary texts. Also, Speech Technique is related to the course The Artistic Word 1 and 2, which is at the AGRFT currently taught by Saša Pavček and Aleš Valič, both actors. Aleš Valič points out that an actor using the artistic word is left without support from his director, lector, dramaturge, other actors and misanscene. He is on his own, left to his own abilities and creativity (Valič, 2000, p. 23). The actor reveals the essence of a text as a whole, and in order to express that, he only has his voice and words at disposal. In The Artistic Word the teachers at Chair of Speech in practical lessons cooperate with lectors, just as is the case with Stage Acting. In that way two approaches, scientific and artistic, are connected. In order to help stage acting students achieve a good artistic interpretation, there must be a cooperation between a mentor who is an actor and a mentor who is a scientist, an expert in the field of stage speech. In that way we again combine theory and practice, science and art. We work with students individually as well, due to individual pronunciation particularities: dialect, minor errors, specific arrangement of teeth, etc.

Apart from that, the knowledge which the students gain in other courses taught at Chair of Speech is applied to the content taught in the major course in Stage Acting and Theatre Directing at the AGRFT, which is Stage Acting $1,2,3$ and 4 . In the practical lessons with lectors they prepare texts used to achieve good speech performance of their students. In productions which are prepared in each semester of the study programme there is a cooperation of stage acting and theatre directing teachers, scenography, costumography, dramaturgy and speech teachers. Practical lessons with lectors start in the initial phase of work on a text. In that phase a text for a play is prepared, which is a sort of a screenplay for the play, but which can to a great extent differ from a dramatic text. This means that the text can be shortened, extended with other texts, its linguistic level can be changed (from a literary text to a spoken text), or it can be modernized. Then a speech basis for further 
work on the text is prepared. We mark stress, work on the meaning of words, phrases and monologues, textual phonetics (pauses, intonation, register, tone of voice, vocality, etc.) (Podbevšek, 1989/1990, p. 27). After that, in the phase when a theatre performance is being prepared, we work on the creative aspect of speech and placement of speech in the overall performance. During staging and especially in the final phase, we correct the speech of stage acting students, guide them and help them resolve the problems they come across.

\section{CONCLUSION}

According to recent research and previous beliefs of theatre theorists and practitioners, it is evident that the synergy between science and art in the education of future actors is extremely important. We believe that the acceptance of scientific methods in the teaching process at artistic academies is still insufficient, regardless of the fact that it has become common at the AGRFT in Ljubljana. It can partially be explained with the choice of teachers at artistic academies who are mostly practitioners. It is our intention to include recent scientific achievement in the teaching process as much as possible. In the paper we have described the teaching methods used in some courses taught in acting study programmes at the two academies, the Academy of Dramatic Art (ADU) in Zagreb, Croatia and at the Academy of Theatre, Radio, Film and Television (AGRFT) in Ljubljana, Slovenia. These courses are: Croatian Stress Patterns, Orthoepy of the Croatian Language, Linguistic Purism and Speech Elegance, The Styles of the Croatian Language and Speech (ADU) and Language and Speech 1, 2 and 3 (AGRFT), followed by the description of work at Chair of Speech (AGRFT). The syllabi for these courses are similar, while in some parts similar ways and content of teaching can be identified. For example, Orthoepy of the Croatian Language (ADU) can be compared to Language 1 and 2 (AGRFT), while The Styles of the Croatian Language and Speech (ADU) can be compared to the course Language and Speech 3 (AGRFT).

It is important to point out that there has been an effort to adjust the protocols for studying, assessment and actors' stage speech descriptions to the recent scientific achievements. If the cooperation between all mentors is good and is carried out in a creative dialogue, then the above described approach to teaching Stage Acting at the AGRFT is very successful, since it is interdisciplinary and it combines the knowledge and skills gained in all other courses taken by students of Stage Acting. This approach combines not only theory and practice, but also science and art and leads to the best possible result - the greatest progress of students, who, in the process of staging a play, realise that the various types of knowledge they have gained in various courses contribute significantly to the final goal - to becoming a good actor and to achieve collectively the best artistic creation. 


\section{REFERENCES}

[1] Gavella, B. (1967). Glumac i kazalište [Actor and Theatre]. Novi Sad: Sterijino pozorje.

[2] Ivas, I. (1993). Izričajna jezgra u hrvatskom jeziku. Doktorska disertacija [Utterance Nucleus in the Croatian Language. Doctoral dissertation]. Zagreb: Sveučilište u Zagrebu.

[3] Podbevšek, K. (1989/1990). Na novo odkriti govor (učna izkušnja na AGRTV) [Redescovering Speech (learning experience from the AGRTV)]. Jezik in slovstvo [Language and Literature], 35(1-2), 27-31.

[4] Podbevšek, K. (1996). Poučevanje jezika in govora na Akademiji [Teaching Language and Speech at the Academy]. In: A. Inkret (Ed.), Akademija za gledališce, radio, film in televizijo: 50 let: 1946-1996 [Academy of Theatre, Radio, Film and Television: 50 years: 1946-1996] (pp. 154-156). Ljubljana: Akademija za gledališče, radio, film in televizijo.

[5] Podbevšek, K. (2006). Uvod [Introduction]. In: K. Podbevšek, T. Gubenšek (Eds.), Kolokvij o umetniškem govoru 2 [Colloquium on Artistic Speech 2] (pp. 7-9). Ljubljana: Akademija za gledališče, radio, film in televizijo, Katedra za govor.

[6] Podbevšek, K., \& Vrban Zrinski, K. (2013). Hrvatski i slovenski scenski govor prve polovice 20. stoljeća (opis pojedinih akustičkih osobitosti) [Slovene and Croatian Actor's Speech in the First Half of the $20^{\text {th }}$ Century (Comparison of Some Acoustical Characteristics)]. In: H. Tivadar (Ed.), Aktualna vprašanja slovanske fonetike, monografija Mednarodne znanstvene fonetične konference SLAVIFON Slovenija 2012 [Current Issues of Slovenian Phonetics, a monograph of SLAVIFON Slovenia 2012, International Phonetics Conference ] (pp. 65-72). Ljubljana: Znanstvena založba Filozofske fakultete.

[7] Predstavitveni zbornik univerzitetnega študijskega programa proe stopnje: Dramska igra [Prospectus: First cycle degree study programme: Stage acting] (2015). Ljubljana: Akademija za gledališče, radio, film in televizijo Univerze v Ljubljani, Oddelek za gledališče in radio. Retrieved from: https://www.agrft.uni-lj.si/sites/www.agrft.uni-lj.si/attachments/predstavitveni_ zbornik_dramska_igra_1._stopnja.pdf.

[8] Silić, J. (2006). Funkcionalni stilovi hrvatskoga jezika [Functional Styles of the Croatian Language]. Zagreb: Disput.

[9] Škarić, I., \& Varošanec-Škarić, G. (1994). Skupna slika govora Hrvatske televizije [Collective Portrayal of Speech on Croatian National Television]. Govor [Speech], XI (1). 1-14.

[10] Škarić, I. (1995). Odlike Hrvatske državne medijske govorničke škole [Characteristics of Croatian National Media Rhetoric School]. Govor [Speech], XII (1). 33-46.

[11] Valič, B. (2000). Raba besede pri igri in interpretaciji besedil [The Use of Words in Play in Text Interpretation]. In: K. Podbevšek, T. Gubenšek (Eds.), Kolokvij o umetniškem govoru [Colloquium on Artistic Speech] (pp. 21-25). Ljubljana: Akademija za gledališče, radio, film in televizijo, Katedra za govor.

[12] Varošanec-Škarić, G. (1995). Govorni stilovi u informativnim emisijama [Speech Styles in News Programmes]. Zagreb: Govor [Speech], XII (1). 71-80.

[13] Varošanec-Škarić, G. (2010). Fonetska njega glasa i izgovora [Phonetic Care of Voice and Pronunciation]. Zagreb: FF press.

[14] Vrban Zrinski, K., \& Varošanec-Škarić, G. (2004). Slušno prepoznavanje hrvatskih naglasaka [Auditory Perception of Croatian Stress (Accent) Patterns]. Govor [Speech], XXI (2). 93-110.

[15] Vrban Zrinski, K. (2013a). Fonetska procjena glumačkoga govora [Phonetic Assessment of Actors' Speech]. Govor [Speech], XXX (1). 21-50.

[16] Vrban Zrinski, K. (2013b). Modalitete prozodičnega poudarjanja v odrskem govoru [The Modalities of Prosodic Prominence in Stage Speech]. In: K. Podbevšek, N. Žavbi Milojević (Eds.), Govor med znanostjo in umetnostjo [Speech between Science and Art] (pp. 225-236). Maribor: Aristej.

[17] Vrban Zrinski, K. (2013c). Prozodijski čimbenici suvremenoga scenskoga glumačkoga govora. Doktorska disertacija [Prosodic Features in Contemporary Actors' Speech. Doctoral dissertation]. Zagreb: Sveučilište u Zagrebu.

[18] Vuletić, B. (2007). Lingvistika govora [Linguistics of Speech]. Zagreb: FF press. 